\title{
As Drogas como Problema Social ${ }^{1}$
}

Michel Misse

Como sociólogo, proponho desvincular analiticamente o tratamento da questão "as drogas como um problema social" como um problema "das drogas". A reação moral e normalizadora que vincula o consumo de diferentes tipos de substâncias a vícios de comportamento é a principal responsável pela criminalização conjuntural dessas substâncias e não está comprovado que apenas e exclusivamente o seu uso seja causa isolada de comportamentos violentos na esmagadora maioria de seus consumidores. A desnormalização do comportamento que se segue, muitas vezes, ao seu consumo, produz uma reação social mais repressiva quanto maior for a desvalorização, pelo consumidor, de que o indivíduo deva manter constante vigilância sobre seu comportamento. A valorização do autocontrole como economia de repressão é o resultado moderno da contenção moral do individualismo e, ao mesmo tempo, o principal propiciador da sedução que a perda temporária do autocontrole exerce sobre o indivíduo moderno. Deixar essa questão de lado, por enquanto, é uma exigência analítica, já que a mídia estilizou, nos últimos anos, a relação drogas/violência de tal modo que a opinião pública sente-se atraída mais uma vez a buscar o culpado na vítima. Abstraído o fator "droga" pelo lado do consumo, o que resta é um mercado ilícito, como qualquer outro conjunturalmente criminalizado: aborto, jogo, contrabando, etc. A diferença principal fica por conta da alta taxa de lucratividade e baixa especialização exigida dos varejistas e, por conseguinte, do alto risco de concorrência envolvido nas transações deste mercado. Como em qualquer mercado ilícito, não pode haver regulação legal dos interesses nem resolução judicial (estatal) dos conflitos. Estratégias aquisitivas ilegais ou criminosas são investidas nesse

\footnotetext{
${ }^{1}$ O texto retoma a conferência apresentada em 2003 no III Simpósio Internacional sobre Alcool e Outras Drogas, no Colégio Brasileiro de Cirurgiões, no Rio de Janeiro. Publicada como cap. 6 do livro de Michel Misse, "Crime e Violência no Brasil Contemporâneo", Rio, Ed. Lumen Juris. 2006 [2a. Tiragem: 2011].
} 
mercado com vistas a oferecerem proteção, sejam partidas dos próprios controladores do varejo, sejam produzidas, sob a forma de extorsão, pelos agentes encarregados da sua repressão legal.

As principais causas das soluções violentas dos conflitos nesse mercado resultam, a meu ver, da sobreposição de dois mercados ilícitos, ambos vinculando economia e poder no próprio núcleo de suas estratégias aquisitivas. 1) Na relação entre os pequenos fornecedores, entre estes e a clientela e entre estes e o capitalizador local, chamado "dono", o mercado varejista das drogas, no Rio, é baseado - por falta de capital de giro, de organizações hierárquicas com um comando único (como no jogo do bicho, a partir de 1980) e por baixa oligopolização dos compradores por atacado - num 'sistema de consignação' de vendas. Por se tratar de mercado não-regulável legalmente, portanto de um mercado definido como um mercado de alto risco e desconfiança recíproca, a solução para o pagamento de dívidas e atrasados segue uma lógica retaliativa, decorrente do receio de que qualquer atenuação regular nas cobranças gere um 'efeito-demonstração' capaz de destruir o varejo e expor seu capitalizador, "o dono" do movimento, à mesma lógica no campo de seus fornecedores.

2) Ao contrário do que ocorre nesse comércio nas classes médias e elites, cujos territórios são apartamentos, telefones e contatos diretos sem a constante presença policial, nas áreas urbanas pobres existem razões táticas (quando não históricas) para que o acesso à clientela dependa do controle operacional de um território físico, que lhe oferece mão-de-obra disponível e com alternativas aquisitivas de igual monta quase nulas, disposição para o enfrentamento com a polícia e pontos de fuga variados.

A disputa por territórios, inicialmente resultante, até meados dos anos 80 , de um projeto de oligopolização, decorre agora do seu contrário, isto é, da baixa oligopolização resultante da constante repressão policial aos territórios e do aumento da desconfiança entre as redes de quadrilhas. Também como ocorreu no jogo do bicho, entre as décadas de 50 e 70, embora numa proporção maior e mais complexa, a violência torna-se o principal recurso para afugentar clientela de uma área ou simplesmente ocupá-la pela força.

Antigamente, existiam pistoleiros contratados para isso; hoje, há soldados do tráfico, assalariados. Quando o "dono" é nascido e criado na própria área, ele tende a assumir um papel de "administrador da justiça", e até mesmo de 
"mediador" dos conflitos, passando a ser relativamente respeitado pelos moradores; quando, pelo contrário, é um "invasor", um "sujeito de fora", as relações com a comunidade tornam-se particularmente tirânicas. 3) Finalmente, um segundo mercado ilícito se sobrepõe a este: o que chamo de "oferta forçada de mercadorias políticas”, entre as quais armas, proteção, o sigilo, a informação, a "liberdade". Policiais trocam (oferecendo ou extorquindo) mercadorias políticas que eles expropriam do Estado, entre as quais as batidas, as blitze e as ocupações dos territórios.

Neste último caso, sua violência é percebida como maior que a dos traficantes, segundo depoimentos que recolhi em diferentes áreas. A lógica da violência alimenta-se assim da sobreposição dos dois mercados, um que oferece drogas a varejo baseado num precário sistema de consignação de vendas, outro que oferece armas e outras mercadorias políticas ao primeiro, retaliando com violência quando a extorsão não é aceita. Não existem formas de acabar totalmente com os dois mercados enquanto houverem clientes para drogas e clientes para mercadorias políticas. A prisão de "donos" e "gerentes" funciona seja como atenuador temporário, em algumas áreas, seja como matriz da rotatividade de novas lideranças ou propiciadora de novas invasões. A prisão dos "policiais corruptos", embora seja moral e legalmente desejável e constitua o melhor começo para a solução, padece de dificuldades e complexidades culturais extraordinárias. Apenas alternativas aquisitivas legais (e não apenas de sobrevivência, como até agora) poderiam atenuar estruturalmente a manutenção desses mercados no nível em que se encontram hoje.

O comércio varejista de drogas no Rio de Janeiro mostra-se abrangente e duradouro, atravessando governos e resistindo às sucessivas invasões, pela polícia, de áreas controladas por traficantes e superando mesmo a prisão continuada de suas principais lideranças nos últimos vinte anos. Seria insano atribuir a este ou aquele governo a responsabilidade de encerrar em uma gestão o que já encontrou consolidado e resistente a vários governos durante tanto tempo. No entanto, sabe-se que praticamente todos os "donos" do varejo foram presos ou mortos pela polícia. Uma questão, portanto, permanece: como é possível aos traficantes, do atacado e do varejo, permanecer com tanta força após terem se tornado os principais alvos da polícia há quase duas décadas? 
Há várias razões e nenhuma é suficiente para dar uma explicação completa: 1) o consumo de drogas não responde apenas a uma demanda inercial, mas é também produzido pela oferta; 2) a oferta se beneficia de uma estrutura não verticalizada, com várias redes de atacado sobrepostas e inúmeras redes de varejo - os chamados "comandos" são antes denominações simbólicas de proteção de presidiários do que uma organização formal e complexa como a que chegou a ocorrer no jogo do bicho; 3) a alta e rápida lucratividade desse mercado informal e ilegal continua a atrair jovens pobres (ou mesmo de classe média) para o "ganho fácil", apesar dos altos riscos de prisão ou morte reconhecidos por todos os que entram para o chamado "movimento"; 4) uma parcela significativa de policiais, agentes penitenciários e outros agentes do Estado "vende" proteção e outras "mercadorias políticas" (expropriadas de suas funções no Estado) a traficantes, permitindo assim a sua impunidade e, mesmo quando presos, a continuar controlando parte de seus negócios fora da prisão; 5) diferentes interesses, de setores bem posicionados na economia e na política, conseguem impedir o desbaratamento das principais rotas do atacado (inclusive de armas), a maior parte das quais destinadas ao mercado externo. Não se pense que a questão do tráfico tem solução rápida e fácil. Todas as vezes que se pensou assim, incrementou-se ainda mais alguns dos fatores que realimentam o próprio mercado de drogas e armas, num círculo vicioso infernal que produz mais violência no varejo e menos apoio das comunidades pobres à ação policial. Diante desse desafio, é preciso uma ação continuada, que priorize a investigação das redes do atacado e diminua o poder dos interesses que invalidam ou tornam juridicamente inócuos os resultados efetivos dessas investigações. O varejo é função do atacado e da larga oferta de mão-de-obra de jovens e não adiantará nada lotar as prisões de pequenos traficantes (ainda que perigosos) se seus fornecedores continuam a atrair outros jovens para sucede-los no atrativo e arriscado negócio. Aqui, a simplificação do problema simplesmente pode provocar seu aumento, que é o que vem ocorrendo há décadas.

Uma última observação: liguei, na minha análise, a violência aos seus acionadores econômicos - um duplo mercado -, mas isso não significa que eu não considere que a violência pode exercer uma atração em si mesma e seu poder de sedução tenha se ampliado com a crise na normalização dos 
comportamentos e a ausência de canais alternativos abrangentes, legalmente regulados, para que a parte da juventude que se sente motivada pela agressividade, possa canalizá-la sem produzir vítimas. No entanto, o estreitamento desses canais, bem como a própria crise na normalização dos comportamentos parece, por sua vez, decorrer também de problemas econômico-sociais mais complexos, que afetam o desenvolvimento do país como um todo. A crescente disjunção entre escola e mercado de trabalho, os baixos salários há três décadas convivendo com um estímulo ao consumo antes nunca visto (mais do que o próprio desemprego) e a crise de autoridade na família (particularmente na família urbana pobre) fazem do comércio de drogas e de mercadorias políticas não apenas um negócio atraente, ma um estilo de vida sedutor, ainda que efêmero.

Muitos dos jovens que entrevistei preferem morrer antes dos 25 anos, com esse estilo de vida, a viver 60 como parias e humilhados. Como fazê-los entender que estão errados? 